\title{
Calendar and thermal time-based growth models for common carp and pikeperch, and the influence of stocking strategy in Lake Balaton, Hungary
}

\author{
András Specziár ${ }^{1, *}$ and Béla Turcsányi ${ }^{2}$ \\ ${ }^{1}$ Balaton Limnological Institute, MTA Centre for Ecological Research, Klebelsberg K. u. 3, 8237 Tihany, Hungary \\ ${ }^{2}$ Balaton Fish Management Non-Profit Ltd., Horgony u. 1, 8600 Siófok, Hungary
}

\begin{abstract}
Common carp Cyprinus carpio and pikeperch Sander lucioperca are widely distributed and economically important freshwater fishes. Because these species are extensively stocked both within and outside of their native ranges, it is important to assess the effect of these actions. We aimed to analyse growth rate and its variability related to stocking strategy (season $\times$ lake area $\times$ habitat $\times$ fish size) in common carp and pikeperch in Lake Balaton (Hungary), based on cooperative tagging experiments with anglers. In both species, length increment was more closely associated with thermal time (degree-day sum) over $8^{\circ} \mathrm{C}$ threshold water temperature than calendar time. Except a marked decrease with increasing fish size, stocking parameters had little effect on length increment. Growth models based on the GROTAG method and the von Bertalanffy's asymptotic length $\left(L_{\infty}\right)$ and growth rate $(K)$ are provided. Compared to other habitats, estimated growth rate proved to be high in common carp (128 mm year ${ }^{-1}$ at $300 \mathrm{~mm}$ standard length) and modest in pikeperch (61 mm year ${ }^{-1}$ at $250 \mathrm{~mm}$ standard length). We concluded that stocking rate even might be increased in common carp, while management of the pikeperch population should rather be based on catch restriction measures than intensified stockings.
\end{abstract}

Keywords: angling / degree-day sum / fisheries management / growth rate / mark and recapture

Résumé - Modèles de croissance basés sur le temps calendaire et thermique pour la carpe commune et le sandre; influence de la stratégie d'empoissonnement au lac Balaton, Hongrie. La carpe commune Cyprinus carpio et le sandre Sander lucioperca sont des poissons d'eau douce largement distribués et économiquement importants. Étant donné que ces espèces sont largement déversées à l'intérieur et à l'extérieur de leur aire de répartition naturelle, il est important d'évaluer l'effet de ces actions. Nous avons cherché à analyser le taux de croissance et sa variabilité liés à la stratégie d'empoissonnement (saison $\times$ superficie du lac $\times$ habitat $\times$ taille du poisson) chez la carpe commune et le sandre du lac Balaton (Hongrie), sur la base d'expériences de marquage en coopération avec les pêcheurs à la ligne. Chez les deux espèces, l'incrément de longueur était plus étroitement associé au temps thermique (somme des degrésjours) au-dessus seuil de $8{ }^{\circ} \mathrm{C}$ pour la température de l'eau que le temps calendaire. Sauf une diminution marquée avec l'augmentation de la taille des poissons, les paramètres d'empoissonnement ont eu peu d'effet sur l'augmentation de la longueur. Des modèles de croissance basés sur la méthode GROTAG, et la longueur asymptotique de von Bertalanffy $\left(L_{\infty}\right)$ et le taux de croissance $(\mathrm{K})$ sont fournis. Par rapport à d'autres habitats, le taux de croissance estimé s'est avéré élevé chez la carpe commune $\left(128 \mathrm{~mm}\right.$ année ${ }^{-1}$ à $300 \mathrm{~mm}$ de longueur standard) et modeste chez le sandre $\left(61 \mathrm{~mm}\right.$ année ${ }^{-1}$ à $250 \mathrm{~mm}$ de longueur standard). Nous avons conclu que le taux d'empoissonnement pourrait même être augmenté chez la carpe commune, alors que la gestion de la population de sandre devrait plutôt être basée sur des mesures de restriction des prises que sur des empoissonnements intensifiés.

Mots-clés : pêche à la ligne / somme de degrés-jours / gestion des pêches / taux de croissance / marquage et recapture

\footnotetext{
*Corresponding author: specziar.andras@okologia.mta.hu
} 


\section{Introduction}

Common carp Cyprinus carpio and pikeperch Sander lucioperca are common native species of considerable ecological role, and high economic and game fishing importance in majority of Eurasian lowland freshwaters. However, due to overexploitation and human induced degradation of spawning and nursery areas, their natural recruitment is usually short to sustain abundant populations (Saulamo and Thoresson, 2005; Freyhof and Kottelat, 2008; Specziár and Erős, 2016). Moreover, there is a high demand for these species outside of their native ranges, too (Hickley and Chare, 2004; Copp et al., 2005). Therefore, aquaculture-reared individuals of common carp and pikeperch are widely used to supplement or maintain their stocks (FAO, 2005-2018).

Since releasing fish to natural ecosystems, on the one hand, represents an ecological risk through food-web interactions (Fickling and Lee, 1983; Vilizzi et al., 2015), and on the other hand, breeding and releasing of fish require high financial and labour investment, it is important to monitor the effect of stocking programs (Arlinghaus et al., 2016). Growth rate of fish can provide valuable supplementary indications in these regards. In general, there is a strong relationship between the growth rate of fish and ecosystem productivity, the density and quality of the available food supply, and the degree of interand intraspecific competition (Kennedy and Strange, 1986; Keskinen and Marjomäki, 2003; Lorenzen, 2016). An insufficient growth rate could be an indication of overstocking and/or inappropriate environmental condition for the stocked species (Arlinghaus et al., 2016). Information about the growth parameters is also essential for the assessment of stock status and sustainable fisheries yields (Lorenzen, 2016). Conditions of releasing, like season, area and body size, however, may also affect the survival rate, distribution and growth of the stocked fish (Gunn et al., 1987; Vostradovský, 1991; Fielder, 1992; Michaletz et al., 2008).

Balaton is a much preferred recreational lake, which fish populations are intensively harvested by angling. Therefore, regular stockings are needed to supplement stocks of the most preferred game fishes, and accordingly, about 350 tons of 2 and 3 years old common carp and 60000 individuals (or 6 tons) of 1year-old pikeperch are released to Lake Balaton, annually. In order to improve the efficiency of these stockings, a fish tagging program was implemented in cooperation with the anglers. Investigations revealed that both recapture rate and distribution of the stocked fish could considerably vary among releasing setups (Specziár and Turcsányi, 2014, 2017). However, it is not yet known how the releasing strategy influences the growth rate of fish and how the stocked fish grow?

Accordingly, in this study we set the goals: (i) to evaluate the effect of releasing strategy (i.e. season $\times$ lake area $\times$ habitat $\times$ fish size) on the length increment of stocked two summer old common carp and one summer old pikeperch, and (ii) to provide models about the length increment of these species in Lake Balaton, by using the information obtained from tagging experiments. Most often, size increment of fish is examined relative to calendar time (Francis, 1988a; Wootton, 1998). However, since instantaneous rate of growth of fish is largely affected by the ambient water temperature, it is suggested that period of growth should preferably be defined as degree-day sum (also known as thermal time approach) at a species-specific threshold temperature, which is an index of the metabolically relevant thermal energy that was experienced over the period of observation (Neuheimer and Taggart, 2007; Chezik et al., 2014). Therefore, to provide more comprehensive analyses, we used both approaches. For research point (i) we hypothesised that length increment of fish, related either to number of days or to degree-day sum, will not be influenced by the stocking season over several years of post-stocking observation period. On the other hand, since primary production increases toward the south-western end (Keszthely basin) of the lake (Istvánovics et al., 2007), we predicted that length increment of fish released at different areas should reflect this pattern. We also predicted that due to the moderate distances between the relevant releasing sites $(c a .2 \mathrm{~km})$, fish could rapidly shift between offshore and inshore habitats, and therefore, habitat of stocking will not influence their growth rate. Finally, in accordance with the general pattern of individual lifetime growth trajectories (von Bertalanffy, 1957; Wootton, 1998), we predicted a marked variance in the growth rate related to fish size at stocking, with smaller length increment in larger size-groups.

\section{Materials and methods}

\subsection{Study area}

This study was conducted on large and shallow Lake Balaton (surface area: $593 \mathrm{~km}^{2}$; mean depth: $3.2 \mathrm{~m}$ ) situated in Hungary, Central Europe (at $46^{\circ} 42^{\prime}-47^{\circ} 04^{\prime} \mathrm{N}, 17^{\circ} 15^{\prime}-18^{\circ} 10^{\prime}$ $\mathrm{E}$ and $104.8 \mathrm{~m}$ above sea level). The lake has recently been recovered from eutrophication to an oligo-mesotrophic state with mean annual chlorophyll- $a$ concentrations of 3.6$18.7 \mathrm{mg} \mathrm{m}^{-3}$, and moderate zooplankton and zoobenthos biomass (Istvánovics et al., 2007). The fish fauna is dominated by cyprinids, of which common bream Abramis brama, bleak Alburnus alburnus, razor fish Pelecus cultratus and the introduced hybrid bigheaded carp Hypophthalmichthys molitrix $\times H$. nobilis are the most abundant in biomass. Common carp occurs mainly in the littoral zone and its abundance basically depends on the actual stocking rate. While, pikeperch, the main piscivorous fish of the lake, lives primarily offshore (Specziár et al., 2009; Specziár, 2010).

\subsection{Tagging and recapture}

For the purpose of this study, all common carp belonging to the same, fully scaled, less domesticated aquaculture strain and pikeperch of semi-natural progeny of Lake Balaton stock (eggs were collected by plastic spawning nets placed into the lake) were hatched and reared in the fish farm of the Balaton Fish Management Non-Profit Ltd (BFMnP). We tagged altogether 4500 two summers old $(170-350 \mathrm{~mm}$ standard length, $L)$ common carp and 3000 one-summer old $(170-310 \mathrm{~mm} L)$ pikeperch with Floy ${ }^{\circledR}$ FD-68BC T-Bar Anchor Tags $(2 \times 38 \mathrm{~mm}$; www.floytag.com $)$ of orange colour, and with unique tag numbers and a reference to the address of the institute to be contacted. Each fish was measured for $L$ and body mass $(M)$ to the nearest $1 \mathrm{~mm}$ and $1 \mathrm{~g}$, respectively. Common carp was released in March, July and NovemberDecember 2010, while pikeperch in December 2012 and March 2013 into the three major basins (Siófok, Szemes and 
Keszthely) of Lake Balaton, from shore and offshore according to a symmetrical experimental design with 250 fish in each group (season $\times$ lake area $\times$ habitat). Only healthy and vigorous fish were used. More detailed description of the tagging procedure, size ranges of fish by stocking trials and releasing of fish is provided in our previous studies (Specziár and Turcsányi, 2014, 2017).

Tagged fish were recaptured and reported by the anglers according to the guide provided to each angling licence and also published in written and electronic media. Anglers were asked to report time and location of the catch, and $L$ and $M$ of the fish at capture. To encourage reporting activity we offered a modest reward ( $c a$. 10 EUR until the end of 2012 and 13 EUR afterwards) for each tag returned. Anglers were distinctly instructed to indicate if they were not able to provide precise data with no effect on their rewarding. Ambiguous data were excluded from the analyses.

\subsection{Data analysis}

Length increment $(\Delta L, \mathrm{~mm})$ of fish was modelled both relative to calendar and thermal time; that is we related $\Delta L$ to number of days $(d)$ and degree-day sum $\left(D,{ }^{\circ} \mathrm{C}\right)$ elapsed between the release and recapture. Degree-day sum calculates as:

$$
D=\sum_{i=1}^{d}\left(T_{i}-T_{\text {threshold }}\right) T_{i}>T_{\text {threshold }}
$$

where $T_{i}$ is the mean daily water temperature at day $i, d$ the number of days of the observation period and $T_{\text {threshold }}$ is the set threshold water temperature. The $T_{\text {threshold }}$ of growth of common carp and pikeperch was assessed by maximizing the coefficient of determination $\left(R^{2}\right)$ in the regression of $\Delta L$ on $D$ via testing all possible round $T_{\text {threshold }}$ values between 0 and $20^{\circ} \mathrm{C}$. Daily water temperature data measured at Siófok were obtained from the Hungarian Meteorological Service.

Recaptured fish were classified into three size groups representing ranges of $\leq 245,246-265$ and $>265 \mathrm{~mm} L$ at release and fish size was included to stocking variables. Accordingly, based on four predictor variables (season $\times$ lake area $\times$ habitat $\times$ fish size), we could evaluate the variability of $\Delta L$ among 54 and 36 different stocking strategies in the common carp and pikeperch, respectively. The effect of stocking variables and their interactions on $\Delta L$ at alternative covariates, the $d$ and $D$, was tested with general linear models (GLM). Because preliminary analysis of variance (ANOVA) indicated that fish size at release differed slightly between stocking seasons (common carp: d. f. $=2 ; 678, F=87.6, P<0.001$; pikeperch: d.f. $=2 ; 505, F=9.2$, $P=0.003$ ), but not between lake areas (common carp: d.f. $=2$; 678, $F=1.8, P=0.167$; pikeperch: d.f. $=2 ; 505, F=0.3$, $P=0.777$ ) and habitats (common carp: d.f. $=1 ; 678, F=0.0$, $P=0.893$; pikeperch: d.f. $=1 ; 505, F=0.0, P=0.867)$ of release in both species, therefore, the effect of stocking season on $\Delta L$ was tested both for the total samples (full GLMs) and for each size group as well. Further, since we expected a strong influence from the lake area on fish growth and many fish moved to other areas after stocking, we also tested the effect of the recapture area on $\Delta L$ at the same alternative covariates, the $d$ and $D$. GLM and ANOVA were performed with Statistica 8.0 software (www. statsoft.com).
Then, length increment of recaptured fish was modelled using the GROTAG method proposed by Francis (1988a). This method uses a maximum likelihood approach to fit the following function on tagging data to estimate $\Delta L$ for an individual $i$ :

$$
\begin{aligned}
\Delta L_{i}= & {\left[\left(\beta g_{\alpha}-\alpha g_{\beta}\right)\left(g_{\alpha}-g_{\beta}\right)^{-1}-L_{i}\right] } \\
& \left\{1-\left[1+\left(g_{\alpha}-g_{\beta}\right)(\alpha-\beta)^{-1}\right]^{\Delta t_{i}}\right\}
\end{aligned}
$$

where $L_{i}$ is the standard length at release, $\Delta t_{i}$ the observation period in years, and $g_{\alpha}$ and $g_{\beta}$ are the estimated growth rates at preselected standard lengths $\alpha$ and $\beta(\alpha=200 \mathrm{~mm}$ and $\beta=300 \mathrm{~mm}$ in common carp and $\alpha=200 \mathrm{~mm}$ and $\beta=250 \mathrm{~mm}$ in pikeperch in this study). In general, $\Delta t_{i}$ is calculated by dividing $d_{i}$, the number of days fish $i$ was at liberty by 365 (Francis, 1988a; Simpfendorfer, 2000), which approach served as the basis of our calendar time based growth model:

$$
\begin{aligned}
& \Delta L_{i}=\left[\left(\beta g_{\alpha}-\alpha g_{\beta}\right)\left(g_{\alpha}-g_{\beta}\right)^{-1}-L_{i}\right] \\
& \left\{1-\left[1+\left(g_{\alpha}-g_{\beta}\right)(\alpha-\beta)^{-1}\right]^{\left(d_{i} 365^{-1}\right)}\right\} .
\end{aligned}
$$

Our alternative model was based on the thermal time and $\Delta t_{i}$ was calculated by dividing $D_{i}$ by the mean annual degree-day sum $\left(D_{\text {annual }}\right)$ calculated for the whole study period (i.e. from 2010 to 2016 in common carp, and from 2013 to 2016 in pikeperch):

$$
\begin{aligned}
& \Delta L_{i}=\left[\left(\beta g_{\alpha}-\alpha g_{\beta}\right)\left(g_{\alpha}-g_{\beta}\right)^{-1}-L_{i}\right] \\
& \left\{1-\left[1+\left(g_{\alpha}-g_{\beta}\right)(\alpha-\beta)^{-1}\right]^{\left(D_{i} D_{\text {annual }}^{-1}\right)}\right\} .
\end{aligned}
$$

This modified approach (Eq. 2b) proportionally incorporates both intra- and inter-annual variability of temperature into the model and more directly than approaches introducing additional seasonal parameters to be estimated (e.g. Cloern and Nichols, 1978; Francis, 1988a). Growth models were optimized by maximizing the following likelihood function:

$$
\lambda=\sum_{i} \log \left[(1-p) \lambda_{i}+p\left(\Delta L_{\max }-\Delta L_{\min }\right)^{-1}\right]
$$

where

$\lambda_{i}=\left[e-0.5\left(\Delta L_{i}-\mu_{i}-m\right)^{2}\left(\sigma_{i}^{2}+s^{2}\right)^{-1}\right]\left[2 \pi\left(\sigma_{i}^{2}+s^{2}\right)\right]^{-0.5}$,

$p$ is the outlier probability, $\mu_{i}$ the expected value of growth increment of fish $i, m$ and $s$ the mean and the standard deviation of the measurement error (assumed to be normally distributed), and $\sigma_{i}$ is the standard deviation of the growth variability $(v)$ assumed to be $\sigma_{i}=v \mu_{i}$ (Francis, 1988a). The likelihood value $(\lambda)$ was maximized using the macro developed by Simpfendorfer (2000) based on the Solver function in 
Microsoft Excel. Although the GROTAG method allowed the use of six parameters (i.e. $g_{\alpha}, g_{\beta}, v, s, m$ and $p$ ), the number of parameters retained in the final model was determined according to the likelihood ratio test, assuming that the addition of a new parameter is significant if $\lambda$ increases by $>1.92$ (Francis, 1988a). Ninety-five percent confidence intervals (CIs) were calculated for each model parameter by bootstrapping the observed $\Delta L$ data 10000 times. In situations where the GLM did not unequivocally reject the effect of season, lake area and habitat of stocking, or lake area of recapture on the $\Delta L$, separate growth models (Eqs. 2a and/or $2 \mathrm{~b}$ ) were composed based on the whole samples and for the relevant releasing set-up variants as well. Note that stocking fish size is a priori included in the growth model.

Based on the optimized model parameters, the von Bertalanffy growth rate $(K)$ and asymptotic length $\left(L_{\infty}\right)$ were also estimated according to Francis (1988a):

$$
\begin{gathered}
K=-\ln \left[1+\left(g_{\alpha}-g_{\beta}\right)(\alpha-\beta)^{-1}\right] \\
L_{\infty}=\left(\beta g_{\alpha}-\alpha g_{\beta}\right)\left(g_{\alpha}-g_{\beta}\right)^{-1} .
\end{gathered}
$$

\section{Results}

\subsection{Recaptures}

Until 31 December, 2016, anglers reported recaptures of altogether 829 common carp and 522 pikeperch of which 684 and 513, respectively, were reported with approved $L$ data. The number of recaptures decreased considerably in time in both species; $83.3 \%$ of recaptures happened in the first, $11.3 \%$ in the second, $2.9 \%$ in the third, $1.5 \%$ in the fourth and altogether $1 \%$ in the fifth year or later after stocking in common carp, while $39.6 \%$ of recaptures happened in the first, $34.5 \%$ in the second, $18.1 \%$ in the third and $7.8 \%$ in the fourth year after stocking in pikeperch. Observed $\Delta L$ ranged from -20 to $470 \mathrm{~mm}$ ( -69 to $11770 \mathrm{~g}$ increment in $M$ ) in common carp and from -10 to $350 \mathrm{~mm}$ ( -48 to $2574 \mathrm{~g}$ increment in $M$ ) in pikeperch.

\subsection{Water temperature threshold of growth}

For majority of the tested $T_{\text {threshold }}$ range, $\Delta L$ proved to be more closely associated with $D$ than $d$ (Fig. 1). In both species, $R^{2}$ values of the correlation between the $\Delta L$ and $D$ increased very slightly or showed a plateau with increasing $T_{\text {threshold }}$ from $0{ }^{\circ} \mathrm{C}$ to $8-9^{\circ} \mathrm{C}$ and then decreased progressively. Therefore, and also in agreement with the temperature related shift in recapture rate by angling (Specziár and Turcsányi, 2014, 2017), we chose $T_{\text {threshold }}=8^{\circ} \mathrm{C}$ for modelling growth of common carp and pikeperch in Lake Balaton.

\subsection{Effect of stocking strategy}

In the common carp, at either $d$ or $D_{8}{ }^{\circ} \mathrm{C}$ covariant, $\Delta L$ varied with fish size (specifically, $\Delta L$ decreased with $L$ at stocking), but not with lake area and habitat of stocking (Tab. 1). Although the full GLM with $d$ as covariant indicated

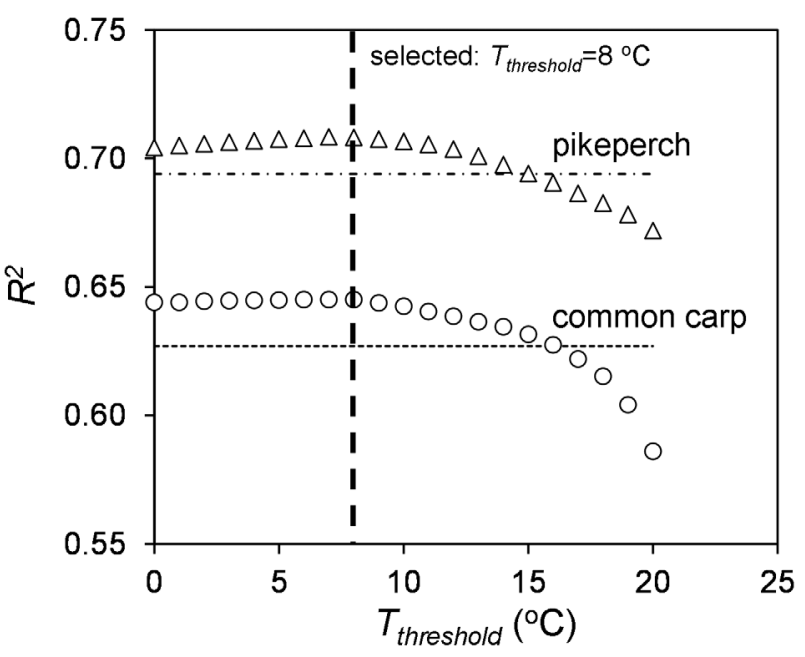

Fig. 1. Goodness of fit $\left(R^{2}\right)$ of regression between degree-day sum $(D)$ and standard length increment $(\Delta L)$ in relation to the threshold water temperature ( $\left.T_{\text {threshold }}\right)$ in tagged common carp $(0 ; n=684)$ and pikeperch $(\Delta ; n=513)$ in Lake Balaton. For reference, $R^{2}$ values of the regression between calendar days and $\Delta L$ are indicated by horizontal lines (. . . . in common carp and $-\cdot \cdot \cdot$ in pikeperch), while the vertical line (- - ) represents the set $T_{\text {threshold. }}$

some stocking season related variability in $\Delta L$ as well, this effect was not clearly approved when the influence of fish size at stocking was controlled. Therefore, differences in the $L$ distribution of fish between the stocking seasons could explain (at least in part) the observed seasonal variability, too. However, no seasonal variability at all was found in $\Delta L$ at covariant $D_{8}{ }^{\circ} \mathrm{C}$. Lake area of recapture proved also not to influence $\Delta L$ in common carp at neither covariates (Tab. 1). Moreover, no considerable factor interactions were revealed, except the marginal effect of fish size $\times$ season $(P=0.045)$ on $\Delta L$ at covariant $d$.

In pikeperch, $\Delta L$ varied with fish size (again, $\Delta L$ decreased with $L$ at stocking), while the lake area and habitat of stocking had no effect on $\Delta L$ at neither covariant $d$ nor $D_{8}{ }^{\circ} \mathrm{C}$ (Tab. 1). In addition, GLM indicated some pure seasonal effect at covariant $d$. Contrary to common carp, however, a weak effect $(P=0.031)$ from the lake area of recapture was also found on the $\Delta L$ at covariant $d$; pikeperch recaptured in the Siófok basin showed less increment then in the Szemes and Keszthely basins. We found no significant factor interaction in the models.

\subsection{Growth models}

Based on the likelihood values, growth of common carp and pikeperch was most efficiently described by four or five parameters GROTAG models (Tab. 2). Adjusted coefficient of determination $\left(R_{\text {adj. }}^{2}=0.576-0.795\right)$ indicated that these models explained a large proportion of variation in the $\Delta L$ data, especially in models, which included $D_{8}{ }^{\circ} \mathrm{C}\left(R^{2}\right.$ adj. $=0.739$ in the common carp and $R_{\text {adj. }}^{2}=0.780$ in the pikeperch).

In common carp, the overall model based on $D_{8}{ }^{\circ} \mathrm{C}$ predicted mean $\Delta L$ of $174,94,51$ and $28 \mathrm{~mm}$ for the first, second, third and fourth year after stocking for individuals released at $200 \mathrm{mmL}$. The same values for common carp 
A. Specziár and B. Turcsányi: Knowl. Manag. Aquat. Ecosyst. 2018, 419, 39

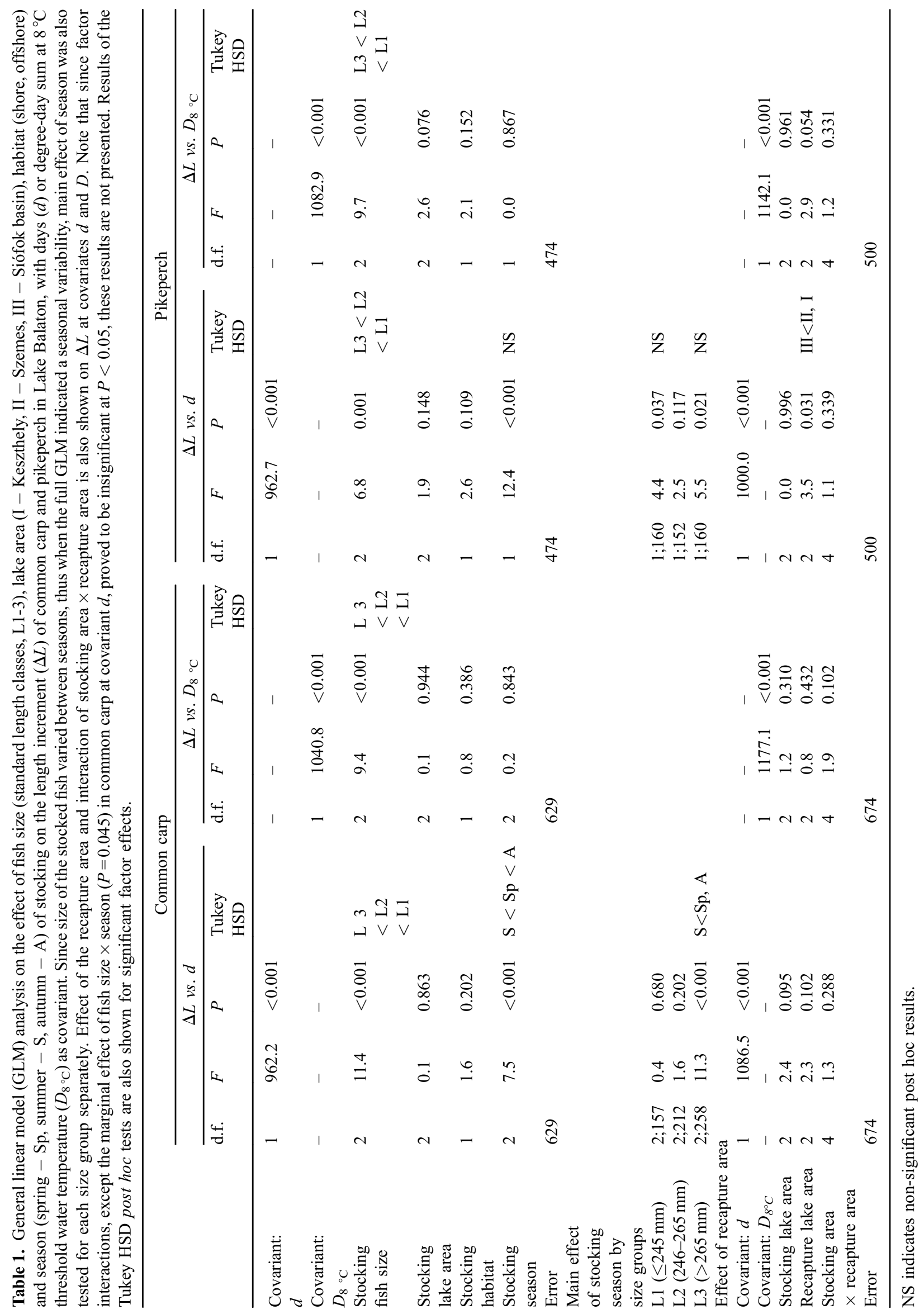


A. Specziár and B. Turcsányi: Knowl. Manag. Aquat. Ecosyst. 2018, 419, 39

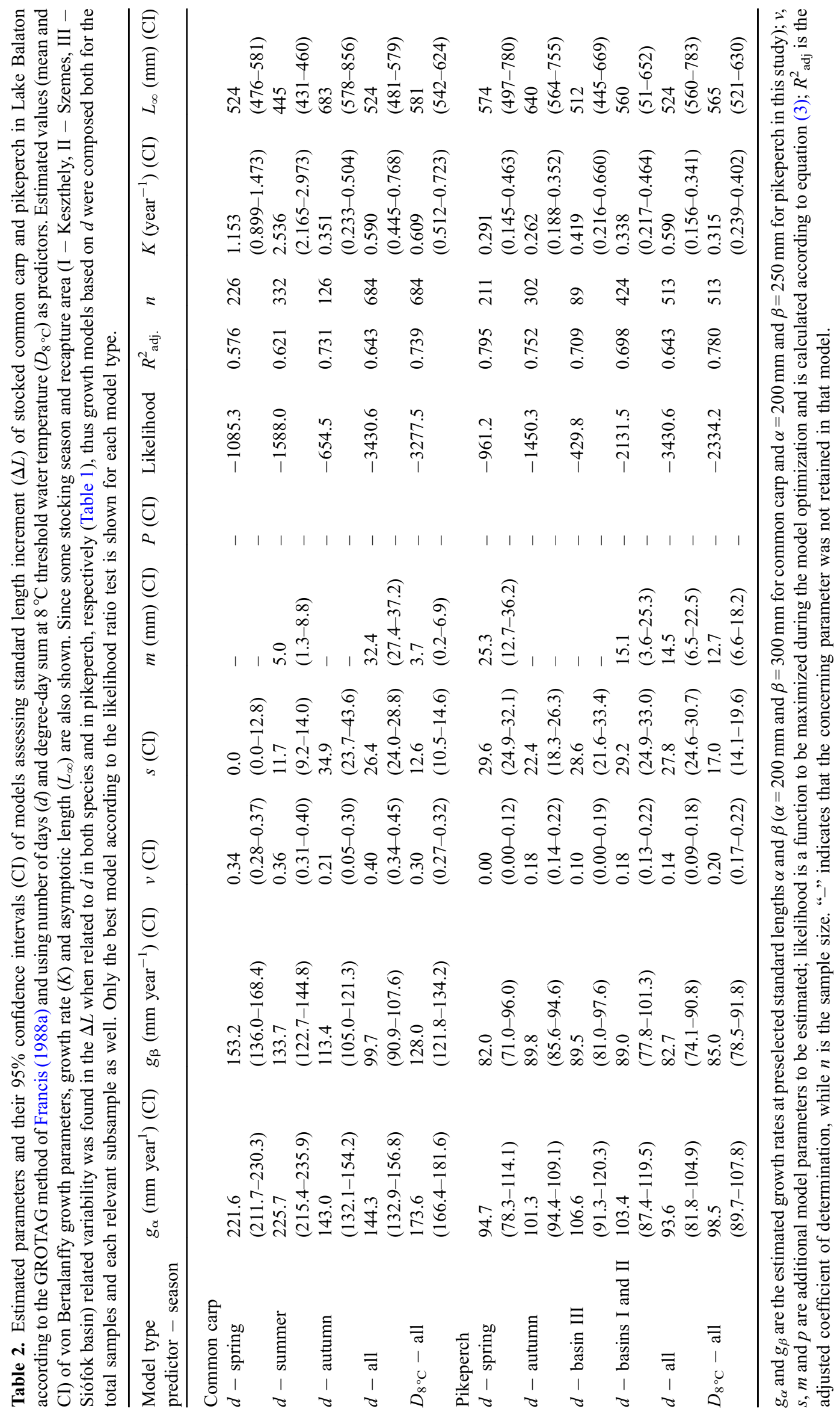



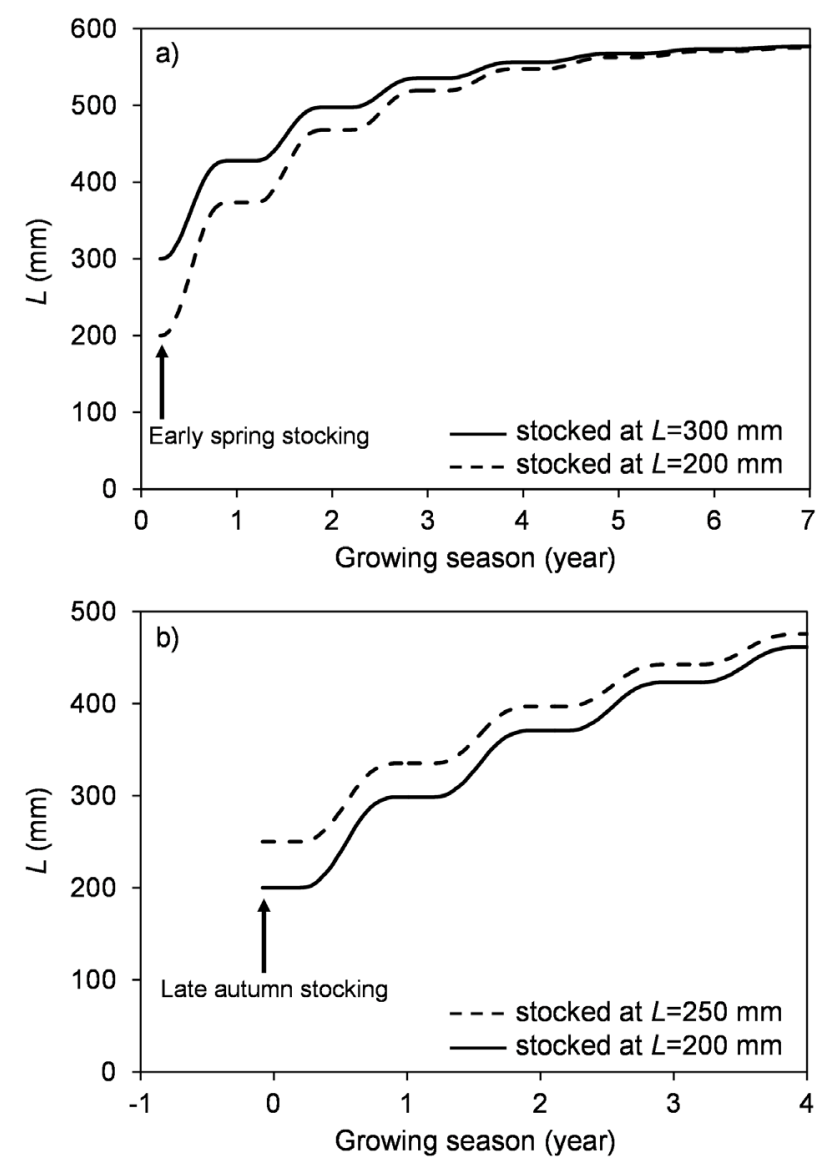

Fig. 2. Mean growth trajectories of stocked and recaptured common carp (a) and pikeperch (b) in Lake Balaton for the suggested stocking season (early spring in common carp, Specziár and Turcsányi 2014; and late autumn in pikeperch, Specziár and Turcsányi 2015) and according to the temperature adjusted GROTAG model of Francis (1988a). Modelled growth is calculated as: $L_{\Delta t}=L_{0}+\Delta L_{\Delta t}$, where $L_{\Delta t}$ is the standard length at $\Delta t$ (years) time after stocking calculated as degree-day sum above $8{ }^{\circ} \mathrm{C}$ threshold water temperature and divided by the mean annual degree-day sum of the concerning study period above the same threshold temperature, $L_{0}$ is the standard length at stocking and $\Delta L_{t}$ is the modelled standard length increment according to equation (2b). Modelled growth is shown for two stocking sizes in each species of which the more typical is indicated by continuous whereas the less typical with broken line.

released at $300 \mathrm{~mm} L$ were $128,70,37$ and $21 \mathrm{~mm}$, respectively (Fig. 2a). Note that these predicted $\Delta L$ values are based on the mean annual $D_{8}{ }^{\circ} \mathrm{C}$ value of $2323^{\circ} \mathrm{C}$ for the whole study period between 2010 and 2016 in Lake Balaton, and actual $\Delta L$ depends on the temperature regime of the considered period as well. Estimated von Bertalanffy parameters of growth based on the same model proved to be $K=0.609$ (95\% CI: 0.512-0.723) year $^{-1}$ and $L_{\infty}=581(542-624) \mathrm{mm}$ (Tab. 2). It should be noted, however, that estimated values of the GROTAG parameters as well as the $K$ and $L_{\infty}$ varied substantially among models and had quite wide $95 \%$ confidence ranges.

In pikeperch, the overall model based on $D_{8}{ }^{\circ} \mathrm{C}$ predicted mean $\Delta L$ of $99,72,52$ and $39 \mathrm{~mm}$ for the first, second, third and fourth year after stocking for individuals released at
$200 \mathrm{~mm} L$. The same values for pikeperch released at $250 \mathrm{~mm} L$ were $85,62,45$ and $33 \mathrm{~mm}$, respectively (Fig. 2b). Note again that these predicted $\Delta L$ values are based on the mean annual $D_{8}{ }^{\circ} \mathrm{C}$ value of $2407^{\circ} \mathrm{C}$ for the period between 2013 and 2016 and actual $\Delta L$ depends on the temperature regime of the considered period. Estimated von Bertalanffy parameters of growth based on the same model proved to be $K=0.315(0.239-0.402)$ year $^{-1}$ and $L_{\infty}=565$ (521-630) $\mathrm{mm}$ (Tab. 2). Again, estimated values of the GROTAG parameters as well as the $K$ and $L_{\infty}$ varied substantially among model types and had quite wide $95 \%$ confidence ranges.

\section{Discussion}

Our tagging experiments with long observation periods resulted in useful amount of growth data for the stocked common carp and pikeperch in Lake Balaton. Results support the judgement that thermal time based growth models provide greater explanatory power than conventional calendar time based models. Moreover, the application of thermal time enables to integrate growth data of fish tagged at different time of the year into a common analysis even in the temperate region.

Calculation of the thermal time, however, requires the assessment of the lower $T_{\text {threshold }}$ of growth of the species studied (Neuheimer and Taggart, 2007). Since we could not find direct estimates about the $T_{\text {threshold }}$ value of the common carp and pikeperch, an attempt was made to assess it from the tagging data. The observed patterns of $R^{2}$ values as function of $T_{\text {threshold }}$ were very similar to that found by Chezik et al. (2014) in eight freshwater species and 81 walleye Sander vitreus populations. Namely, $R^{2}$ values were similar and high for small values of $T_{\text {threshold }}$, and then dropped of progressively in both common carp and pikeperch. Therefore, considering the proof for a daily growth rate as high as $0.7 \%$ of body mass even at $12{ }^{\circ} \mathrm{C}$ water temperature (Goolish and Adelman, 1984), the intensive feeding to as low as $8^{\circ} \mathrm{C}$ water temperature (Specziár and Turcsányi, 2014), and the pattern of $R^{2}$ values for the regression between $D$ and $\Delta L$, we assumed that the lower $T_{\text {threshold }}$ of growth of common carp could be $8^{\circ} \mathrm{C}$ in Lake Balaton. Mooij et al. (1994) estimated the $T_{\text {threshold }}$ of zero growth for $9.8^{\circ} \mathrm{C}$ in planktivorous and $8.6^{\circ} \mathrm{C}$ in piscivorous age- 0 pikeperch in Lake Tjeukemeer. At the same time, Frisk et al. (2012) concluded that the temperature optima of the adult pikeperch could range from 10 to $27^{\circ} \mathrm{C}$ in term of $>80 \%$ of the maximal metabolic scope (related to growth potential). Therefore, the minimum temperature of growth of adult pikeperch actually seems to be lower than the commonly applied $T_{\text {threshold }}=10^{\circ} \mathrm{C}$ (Kjellman et al., 2001; Lappalainen et al., 2009), and accordingly, we adopted the $T_{\text {threshold }}=8^{\circ} \mathrm{C}$ value resulted from the $R^{2}$ approach in Lake Balaton.

Either related to calendar or thermal time, growth rate of common carp and pikeperch depended most on their length at release, which is in accordance with our understanding on the general nature of fish growth. Although this finding contributes little to stock management strategies, it is important from the point of view of growth modelling and validates the selection of the Francis (1988a) method, which was derived from the von Bertalanffy (1957) framework. 
Variation in food resource is one of the most important factors influencing fish growth. For example, Keskinen and Marjomäki (2003) revealed a strong correlation between primary production and size of age- 3 pikeperch across 41 lakes in central Finland. While, Weber et al. (2010) found a marked relationship between primary production and condition of common carp in 84 lakes and impoundments in the upper Midwest United States. In this study, result on the effect of lake area representing a trophic gradient, however, proved to be less clear-cut. The locality of stocking had no effect on the length increment of fish. This indicates that we cannot influence the growth of stocked common carp and pikeperch in Lake Balaton by varying the area of release, but it does not necessarily mean that growth rate of fish does not respond to spatial differences in lake productivity. It is well known that stocked fish reared in aquaculture may exhibit considerable post-releasing foraging movement and travel long distances (Bolland et al., 2009). Such movements were observed in stocked pikeperch and common carp in Lake Balaton, also (Specziár and Turcsányi, 2014, 2017). On the other hand, since acclimatised common carp and pikeperch generally show strong site fidelity (Keskinen et al., 2005; Jones and Stuart, 2007), we could suppose that length increment of stocked fish that spent long enough time in the lake should reflect differences in productivity between areas of recapture. After all, the area of recapture had also no effect on the growth of common carp and only slightly influenced the growth of pikeperch. The better growth of stocked pikeperch recaptured in the Keszthely and Szemes basins compared to the Siófok basin is in accordance with the productivity gradient of Lake Balaton (Istvánovics et al., 2007). Moreover, this result coincides also with the higher survival rate (monitored as recapture rate) of pikeperch stocked into the Keszthely and Szemes basins than into the Siófok basin likely due to the better feeding conditions (Specziár and Turcsányi, 2017). Finally, post-releasing movements of pikeperch also prevailed towards the more productive areas (Specziár and Turcsányi, 2017). Therefore, Keszthely and Szemes basins are likely more favourable areas for pikeperch than the Siófok basin. Contrary to pikeperch, common carp lives primarily in the littoral zone and feeds mainly on dreissenid mussels in Lake Balaton (Specziár and Rezsu, 2009). Food resources in the littoral zone are distributed more heterogeneously and do not reflect the trophic gradient of the offshore area (Balogh et al., 2008; Árva et al., 2015). The uniform growth rate of common carp in the lake coincides with the area independent pattern of its survival (recapture) rate and post-stocking movements as well (Specziár and Turcsányi, 2014).

Although littoral and offshore habitats differ considerably in their environmental characteristics, including a marked divergence in food resources, habitat of stocking did not influence the growth of common carp and pikeperch in Lake Balaton. Recapture patterns indicated that these species could find their suitable habitat rapidly; the common carp moves to the littoral zone while the pikeperch to the offshore zone (Specziár and Turcsányi, 2014, 2017).

Our results did not categorically support the hypothesis that season of stocking do not influence the growth of the stocked fish when post-stocking observation period covers several years. Some season related variability was revealed in the calendar time-based growth rate of the largest size group of common carp and the smallest and largest size groups of pikeperch. Since such effect did not exist in analyses based on thermal time, the observed seasonal effect likely is a consequence of the limit of calendar time predicting fine changes in the growth rate, especially at the beginning of the post-stocking period between fish released in or out of the growing season.

Growth rate of the common carp proved to be high during the first 2 years after stocking, but then the growth curve started to approach an asymptote (Fig. 2a). The observed initial growth rate $\left(128 \mathrm{~mm} \mathrm{year}^{-1}\right.$ at $300 \mathrm{~mm} L$, according to the thermal time based overall model) was similar to that found in Lake Balaton in the late 1990s based also on cooperative tagging study (132 $\mathrm{mm}$ year $^{-1}$ at $294 \mathrm{~mm} L$; recalculated from $M$ data of Tölg et al. (1997), according to the $L-M$ relationship given in Specziár, 2010), but higher than values assessed based on scale analysis (98 $\mathrm{mm}_{\text {year }}{ }^{-1}$ at $289 \mathrm{~mm} \mathrm{~L}$; Specziár, 2010). Analysing the huge amount of information available worldwide on age-length relationship of common carp, Vilizzi and Copp (2017) provided a reference review. Unfortunately, growth parameters (i.e. von Bertalanffy parameters) obtained from age-length and tagging data are not directly comparable (Francis, 1988b). Therefore, to compare our results to average growth rate of common carp, we calculated 1 year length increment of an $L=300 \mathrm{~mm}$ common carp based on the relevant von Bertalanffy growth functions of Vilizzi and Copp (2017, see Tab. 1 of that publication) and the conversion function between fork and standard length (see Eq. 3a in Vilizzi and Copp, 2017). The calculated average growth rates at $300 \mathrm{~mm} L$ proved to be $53 \mathrm{~mm}$ year ${ }^{-1}$ at global scale and $57 \mathrm{~mm} \mathrm{year}^{-1}$ in the temperate zone, which are less than half of the values observed in Lake Balaton. The prominently high growth rate of common carp indicates plentiful food supply related to high abundance of dreissenid mussels in Lake Balaton. Dreissenia polymorpha and D. bugensis, form large beds, have high productivity (Balogh et al., 2008) and are not utilized to a significant extent by other fish species except the oldest age classes of roach, Rutilus rutilus (Specziár and Rezsu, 2009). In addition, although common carp is stocked regularly into the lake, its mean density is still low (Specziár et al., 2009; Specziár, 2010) because of the intensive catchand-take angling, and therefore, no significant intra-species competition can be expected.

Present results indicated a somewhat higher average growth rate $\left(85 \mathrm{~mm}\right.$ year $^{-1}$ at $250 \mathrm{~mm} L$, according to the thermal time based overall model) of pikeperch, than found in the $1960 \mathrm{~s}$ (61 mm year ${ }^{-1}$ at $250 \mathrm{~mm} L$; Bíró, 1970) and 1970s (66-79 mm year $^{-1}$ at $250 \mathrm{~mm} L$, calculated from the von Bertalanffy functions provided for different lake areas by Bíró, 1985). Compared to other habitats, the growth rate of pikeperch is low in Lake Balaton (Bíró, 1970; Harka, 1977; Bíró, 1985; Copp et al., 2003), because of the unfavourable feeding conditions, at least to $500 \mathrm{~mm} L$ (Bíró, 1973; Specziár, 2011). For example, even though the colder climate, tagging experiments revealed much higher growth rate of pikeperch in Lake Mälaren (Sweden) (Andersson et al., 2015). Based on the published function (Eq. 1 in Andersson et al., 2015), pikeperch released at $250 \mathrm{~mm} L$ could have an average growth rate of $128 \mathrm{~mm} \mathrm{year}^{-1}$ in 1995 , at annual degree-day sum above $10^{\circ} \mathrm{C}$ of $934^{\circ} \mathrm{C}$ (cf. $1611-1984^{\circ} \mathrm{C}$ in Lake Balaton, during 2010 2016), in Lake Mälaren. 
Compared to ordinary field studies relying upon age estimates of varying reliability (Campana, 2001), tagging experiments provide direct information about the time period of the observed size increment for each individual recaptured, and therefore, could support more sophisticated analysis of fish growth. However, present study is based on stocked individuals and recaptures by anglers, which circumstances may limit the generalization of the observed growth rates for the whole stocks at least due to two reasons. First, common carp but not pikeperch (which were direct and diversified progeny of the natural population of Lake Balaton) was obtained from aquaculture stocks domesticated to a degree and therefore may differ in their growth potential genetically from those of the small existing natural stock in the lake. Second, it has been shown that anglers tend to catch individuals that grow faster than the stock average (Raat, 1985; Miranda et al., 1987), and therefore, cooperative tagging studies may overestimate average growth rate of the whole stock. Nevertheless, these limits do not influence the conclusions related to study goals and fisheries management issues.

To conclude, using thermal time instead of the calendar time we can model the length increment of tagged common carp and pikeperch with better explanatory power, including seasonal patterns also. We demonstrated that within the range of relevant variants, stocking strategy has little or no direct effect on the growth rate of these species in Lake Balaton. Analyses revealed that growth rate of common carp is great and the present stocking rate is likely well within the carrying capacity of Lake Balaton. On the other hand, the moderate growth rate of pikeperch indicates that there could not be too much potential to increase population density without adverse environmental and population level effects. Therefore, the management of this species should rather be based on restrictive measures (like sharpening catch quotas) then on intensified stockings.

Acknowledgements. The authors would like to thank Ferenc Bertalan, Géza Dobos, János Fléger, Miklós Ihász and Róbert Tatár for their contribution in tagging and releasing common carp and pikeperch into Lake Balaton, anglers reporting correct data on the capture of tagged fish, and Colin Simpfendorfer for providing the Excel macromanaging the GROTAG model. Fish, tags and rewarding of recapture reports was founded by the Balaton Fish Management Non-Profit Ltd, while analysis of data and writing of the paper was supported by the GINOP 2.3.2-15-2016-00004 project.

\section{References}

Andersson M, Degerman E, Persson J, Ragnarsson-Stabo H. 2015. Movements, recapture rate and length increment of tagged pikeperch (Sander lucioperca) - a basis for management in lakes. Fish Manag Ecol 22: 450-457.

Arlinghaus R, Lorenzen K, Johnson BM, Cooke SJ, Cowx IG. 2016. Management of freshwater fisheries: addressing habitat, people and fish. In: Craig JF, ed. Freshwater Fisheries Ecology. Oxford: Wiley, pp. $557-579$.

Árva D, Tóth M, Horváth H, Nagy SA, Specziár A. 2015. The relative importance of spatial and environmental processes in distribution of benthic chironomid larvae within a large and shallow lake. Hydrobiologia 742: 249-266.
Balogh C, Muskó IB, G-Tóth L, Nagy L. 2008. Quantitative trends of zebra mussels in Lake Balaton (Hungary) in 2003-2005 at different water levels. Hydrobiologia 613: 57-69.

Bíró P. 1970. Investigation of growth of pike-perch (Lucioperca lucioperca L.) in Lake Balaton. Ann Inst Biol (Tihany) 37: 145-164.

Bíró P. 1973. The food of pike-perch (Lucioperca lucioperca L.) in Lake Balaton. Ann Inst Biol (Tihany) 40: 159-183.

Bíró P. 1985. Dynamics of pike-perch, Stizostedion lucioperca L. in Lake Balaton. Int Rev Hydrobiol 70: 471-490.

Bolland JD, Cowx IG, Lucas MC. 2009. Dispersal and survival of stocked cyprinids in a small English river: comparison with wild fishes using a multi-method approach. J Fish Biol 74: 2313-2328.

Campana SE. 2001. Accuracy, precision and quality control in age determination, including a review of the use and abuse of age validation methods. J Fish Biol 59: 197-242.

Chezik KA, Lester NP, Venturelli PA. 2014. Fish growth and degreedays I: selecting a base temperature for a within-population study. Can J Aquat Sci 71: 47-55.

Cloern JR, Nichols FH. 1978. A von Bertalanffy growth model with a seasonally varying coefficient. J Fish Res Bd Can 35: 1479-1482.

Copp GH, Wesley KJ, Kováč V, Ives MJ, Carter MG. 2003. Introduction and establishment of the pikeperch Stizostedion lucioperca (L.) in Stanborough Lake (Hertforshire) and its dispersal in the Thames catchment. Lond Nat 82: 139-153.

Copp GH, Bianco PG, Bogutskaya NG, Erös T, Falka I, Ferreira MT, Fox MG, Freyhof J, Gozlan RE, Grabowska J, Kováč V, MorenoAmich R, Naseka AM, Penáz M, Povž M, Przybylski M, Robillard M, Russell IC, Stakėnas S, Šumer S, Vila-Gispert A, Wiesner C. 2005. To be, or not to be, a non-native freshwater fish? J Appl Ichthyol 21: 242-262.

FAO (2005-2018). World inventory of fisheries. Stocking techniques for increased production. Issues Fact Sheets. In: FAO Fisheries and Aquaculture Department. Rome. Updated 27 May 2005. http:// www.fao.org/fishery/ (Downloaded on 16 March 2018).

Fickling NJ, Lee RLG. 1983. A review of the ecological impact of the introduction of the zander (Stizostedion lucioperca L.) into waters of the Eurasian mainland. Fish Manag 14: 151-155.

Fielder DG. 1992. Evaluation of stocking walleye fry and fingerlings and factors affecting their success in lower Lake Oahe, South Dakota. N Am J Fish Manag 12: 336-345.

Francis RICC. 1988a. Maximum likelihood estimation of growth and growth variability from tagging data. NZJMar Freshw Res 22: 42-51.

Francis RICC. 1988b. Are growth parameters estimated from tagging and age-length data are comparable? Can J Aquat Sci 45: 936-942.

Freyhof J, Kottelat M. 2008. Cyprinus carpio. The IUCN Red List of Threatened Species 2008: e.T6181 A12559362.

Frisk M, Skov PV, Steffensen JF. 2012. Thermal optimum for pikeperch (Sander lucioperca) and the use of ventilation frequency as a predictor of metabolic rate. Aquaculture 324-325: 151-157.

Goolish EM, Adelman IR. 1984. Effects of ration size and temperature on the growth of juvenile common carp (Cyprinus carpio L.). Aquaculture 36: 27-35.

Gunn JM, McMurtry MJ, Bowlby JN, Casselman JM, Liimatainen VA. 1987. Survival and growth of stocked lake trout in relation to body size, stocking season, lake acidity, and biomass of competitors. Trans Am Fish Soc 116: 618-627.

Harka Á. 1977. Growth of pike-perch (Lucioperca lucioperca L.) in the Tisza stretch at Tiszafüred. Tiscia (Szeged) 12: 109-115.

Hickley P, Chare S. 2004. Fisheries for non-native species in England and Wales: angling or the environment? Fish Manag Ecol 11:203212.

Istvánovics V, Clement A, Somlyódy L, Specziár A, G.-Tóth L, Padisák J. 2007. Updating water quality targets for shallow Lake 
Balaton (Hungary), recovering from eutrophication. Hydrobiologia 581: 305-318.

Jones MJ, Stuart IG. 2007. Movements and habitat use of common carp (Cyprinus carpio) and Murray cod (Maccullochella peelii peelii) juveniles in a large lowland Australian river. Ecol Freshw Fish 16: 210-220.

Kennedy GJA, Strange CD. 1986. The effects of intra- and interspecific competition on the survival and growth of stocked juvenile Atlantic salmon, Salmo salar L., and resident trout, Salmo trutta L., in an upland stream. J Fish Biol 28: 479-489.

Keskinen T, Marjomäki TJ. 2003. Growth of pikeperch in relation to lake characteristics: total phosphorus, water colour, lake area and depth. J Fish Biol 63: 1274-1282.

Keskinen T, Pääkkönen JPJ, Lilja J, Marjomäki TJ, Karjalainen J. 2005. Homing behaviour of pikeperch (Sander lucioperca) following experimental transplantation. Boreal Env Res 10: 119-124.

Kjellman J, Lappalainen J, Urho L. (2001). Influence of temperature on size and abundance dynamics of age- 0 perch and pikeperch. Fish Res 53: 47-56.

Lappalainen J, Milardi M, Nyberg K, Venäläinen A. 2009. Effects of water temperature on year-class strengths and growth patterns of pikeperch (Sander lucioperca (L.)) in the brackish Baltic Sea. Aquat Ecol 43: 181-191.

Lorenzen K. 2016. Toward a new paradigm for growth modelling in fisheries stock assessments: embracing plasticity and its consequences. Fish Res 180: 4-22.

Michaletz PH, Wallendorf MJ, Nicks DM. 2008. Effects of stocking rate, stocking size and angler catch inequality on exploitation of stocked channel catfish in small Missouri impoundments. $N \mathrm{Am} \mathrm{J}$ Fish Manag 28: 1486-1497.

Miranda LE, Wingo WM, Muncy RJ, Bates TD. 1987. Bias in growth estimates derived from fish collected by anglers. In: Summerfelt RC, Hall GE, eds. Age and Growth of Fish. Ames: Iowa State University Press, pp. 211-220.

Mooij WM, Lammens EHRR, van Densen WLT. 1994. Growth rate of $0+$ fish in relation to temperature, body size and food in shallow eutrophic Lake Tjeukemeer. Can J Aquat Sci 51: 516-526.

Neuheimer AB, Taggart CT. 2007. The growing degree-day and fish size-at-age: the overlooked metric. Can J Aquat Sci 64: 375-385.

Raat AJP. 1985. Analysis of angling vulnerability of common carp, Cyprinus carpio L., in catch-and-release angling in ponds. Aquacult Fish Manag 16: 171-187.

Saulamo K, Thoresson G. 2005. Management of pikeperch migrating over management areas in a Baltic Archipelago area. Ambio 34: $120-124$.

Simpfendorfer CA. 2000. Growth rates of juvenile dusky shark, Carcharhinus obscurus (Lesueur, 1818), from southwestern Australia estimated from tag-recapture data. Fish Bull 98: 811-822.
Specziár A. 2010. Fish fauna of Lake Balaton: stock composition, living conditions of fish and directives of the modern utilization of the fish stock. Acta Biol Debr Suppl Oecol Hung 23 (Hydrobiol Monogr vol. 2): 7-185. (In Hungarian with an English summary).

Specziár A. 2011. Size-dependent prey selection in piscivorous pikeperch Sander lucioperca and Volga pikeperch S. volgensis shaped by bimodal prey size distribution. J Fish Biol 79: 18951917.

Specziár A, Erős T. 2016. Freshwater resources and fisheries in Hungary. In: Craig JF, ed. Freshwater Fisheries Ecology. Oxford: Wiley, pp. 196-200.

Specziár A, Rezsu E. 2009. Feeding guilds and food resource partitioning in a lake fish assemblage: an ontogenetic approach. $J$ Fish Biol 75: 247-267.

Specziár A, Turcsányi B. 2014. Effect of stocking strategy on distribution and recapture rate of common carp Cyprinus carpio L., in a large and shallow temperate lake: implications for recreational put-and-take fisheries management. J Appl Ichthyol 30: 887-894.

Specziár A, Turcsányi B. 2017. Management of pikeperch stocking in Lake Balaton: effect of season, area, fish size and method of release on the rate and distribution of recaptures. Knowl Manag Aquat Ecosyst 418: article No. 52.

Specziár A, Erős T, György ÁI, Tátrai I, Bíró P. 2009. A comparison between the benthic Nordic gillnet and whole water column gillnet for characterizing fish assemblages in the shallow Lake Balaton. Ann Limnol - Int J Lim 45: 171-180.

Tölg L, Specziár A, Bíró P. 1997. Studies on the carp (Cyprinus carpio L.) stocks in Kis-Balaton Reservoir and Lake Balaton. Hidrol Közl 77: 52-54. (In Hungarian with an English summary).

Vilizzi L, Copp GH. 2017. Global patterns and clines in the growth of common carp Cyprinus carpio. J Fish Biol 91: 3-40.

Vilizzi L, Tarkan AS, Copp GH. 2015. Experimental evidence from causal criteria analysis for the effects of common carp Cyprinus carpio on freshwater ecosystems: a global perspective. Rev Fish Sci Aquacult 23: 253-290.

von Bertalanffy L. 1957. Quantitative laws in metabolism and growth. Q Rev Biol 32: 217-231.

Vostradovský J. 1991. Carp (Cyprinus carpio L.) "put-and-take" fisheries in the management of angling waters in Czechoslovakia. In: Cowx IG, ed. Catch effort sampling strategies. Their application in freshwater fisheries management. Fishing New Books, Oxford: Blackwell, pp. 100-107.

Weber MJ, Brown ML, Willis DW. 2010. Spatial variability of common carp populations in relation to lake morphology and physicochemical parameters in the upper Midwest United States. Ecol Freshw Fish 19: 555-565.

Wootton RJ. 1998. Ecology of Teleost Fishes, 2nd ed., Fish and Fisheries Series 24. Dordrecht: Kluwer Academic Publisher.

Cite this article as: Specziár A, Turcsányi B. 2018. Calendar and thermal time-based growth models for common carp and pikeperch, and the influence of stocking strategy in Lake Balaton, Hungary. Knowl. Manag. Aquat. Ecosyst., 419, 39. 